\title{
LA AMBIGÜEDAD DE LA ESCRITURA ${ }^{1}$
}

\author{
Simón ROYO HERNÁNDEZ
}

\section{Del mito al logos: el nacimiento de la historiografía}

En Grecia no sólo nace la Filosofia con el paso del Mito al Logos sino igualmente la Historia, el registro escrito de los sucesos de forma que los verdaderos hechos del pasado no sean magnificados por la tradición sino conocidos tal y como sucedieron. El desarrollo hasta la escritura geométrica del diálogo de Platón es paralelo al desarrollo que llevó a la tradición mítica hasta la historiografía de Tucidides frente a la oralidad de los poetas.

Los relatos religiosos de la antigua Grecia (tradición politeísta) siguen un proceso similar al de los relatos inspirados de la tradición monoteísta (Antiguo Testamento, Nuevo Testamento, Corán) -e incluso de las tradiciones asiáticas, incluidas las de Oriente Próximo, y amerindias-, un periodo de transmisión oral mayor o menor según el caso, precede a su redacción escrita y a su fijación estable o canónica. La diferencia estriba en la adogmaticidad de los primeros, frente al celo dogmático de los segundos, presuntos escritos inspirados revelados de una vez para siempre. La segunda diferencia fundamental radica en que el estudio de las tradiciones religiosas muertas no hiere ninguna susceptibilidad confesional, mientras que con las religiones aún vivas y con practicantes la investigación puede ser mal vista o repudiada. Mientras que los griegos empezaron a discrepar históricamente de sus propios relatos míticos en el siglo $\mathrm{V}$ a.C., las discrepancias históricas respecto a los escritos monoteístas arábigo-

1 E-mail del autor: «siroyo@rocketmail.com». 
judeo-cristianos no podrán ser públicamente manifestadas sin riesgo de represalias hasta el siglo XIX d.C., cuando nacen la filología y las disciplinas historiográficas modernas, aunque en algunos lugares haya que haber esperado hasta el XX. Hoy en día, en nada debemos diferenciar el estudio de la mitología griega de la investigación de las mitologías arábigo-judeo-cristianas y lo aplicable a Homero en estas páginas resulta perfectamente aplicable a las demás. Ya no hay riesgo de que la verdad de los hechos escandalice o repugne y provoque represalias, al menos en los países aconfesionales de Occidente. Que la tierra se mueva - Galileo- ya no escandaliza a los creyentes. Si el teorema de pitágoras hiere los sentimientos religiosos de alguna persona lo sentimos mucho, no somos nosotros quienes le herimos sino la verdad, también el médico hace daño cuando nos cauteriza una herida y, sin embargo, nos está curando....

La Guerra de Troya tuvo lugar hacia el siglo XIII a.C. y entre los siglos IX y VIII se compondrían y transmitirían oralmente los relatos poéticos sobre el suceso (Homero Cantor); posteriormente, hacia el siglo VII a.C. se produciría la primera redacción o compilación escrita de dichas narraciones (Iliada; Homero Compilador o Escritor) y poco más o menos en esa misma época serían escritas las principales obras de Hesíodo (s.VIII-VII). Entre los siglos VII al $\mathrm{V}$ a.C. no sólo surgen los pensadores que conocemos como Presocráticos, primero, y Sofistas, después, sino que tiene lugar la primera obra histórica o semihistórica, de la mano de Heródoto (526-427 a.C.), y, menos de un siglo después, una segunda obra, ya plenamente histórica, de la mano de Tucídides de Atenas (460-395 a.C.). Con lo cual, vemos en el surgimiento de la Historia un movimiento paralelo y correlativo al que se produce en el ámbito de la Filosofia, sin los cuales no son explicables las apariciones de un Sócrates, primero, y de un Platón y un Aristoteles, después.

El primer Exodo judío, el de Egipto, coincide cronológicamente con la guerra de Troya, puesto que ambos hechos son datados hacia el s.XIII a.C., si bien sólo del segundo existe evidencia arqueológica. Pero será después del segundo Exodo, tras la cautividad en Babilonia, fechado hacia el s.VI a.C., cuando entre una de esas tribus semitas y nómadas del desierto, los hebreos, procedentes de la Península Arábiga y finalmente, semisedentarizados en Palestina, surgirá algo así como el esbozo de un estado independiente y una forma de vida singular, apoyadas sobre la Alianza (bêrit) y la tierra prometida que relata el Génesis, sobre la diáspora y la promulgación de la ley del Sinaí que refiere el Exodo, sobre los llamados cinco libros de Moisés, en definitiva, que 
componen la Ley o Torah, para los judíos: el conjunto de libros que narran la Historia de la Alianza con Yahvé. Los textos más antiguos de este grupo se remontan al siglo X a.C., (época de las monarquías de Saul, David y Salomón; y de la división entre Judá e Israel), otra posible analogía cronológica entre los escribas judíos que redactaron la tradición oral del pueblo elegido y los escritores que conocemos bajo el nombre de Homero, compositores de la Ilíada y la Odisea.

El comienzo de la Iliada de Homero, nos muestra una obra cantada por un anónimo poeta inspirado, a través del cual se pronuncia la Musa: "Canta, oh diosa, la cólera del Pelida Aquiles; cólera funesta que causó infinitos males a los aqueos y precipitó al Hades muchas almas valerosas de héroes» (Canto-I). Hesíodo, comienza su Teogonía y sus Trabajos y Dias, hablando de las Musas, aunque ya nos ofrezca datos personales de su personalidad y autoría, que comparte con las divinidades: "Ellas precisamente enseñaron una vez a Hesíodo un bello canto mientras apacentaba sus ovejas al pie del divino Helicón. Este mensaje a mí en primer lugar me dirigieron las diosas, las Musas Olímpicas, hijas de Zeus portador de la égida: 'iPastores del campo, triste oprobio, vientres tan sólo! Sabemos decir muchas mentiras con apariencia de verdades; y sabemos, cuando queremos, proclamar la verdad'" (Teogonía, vv.22-29).

"Mucho mienten los poetas» decía ya Solón de Atenas (E.Diehl fr.21). Pero será Heródoto ${ }^{2}$, quien represente el nacimiento de la Historia frente a la Mitologia. Aunque denomine a su obra: Los nueve libros de la Historia, con el nombre de las nueve Musas ${ }^{3}$, inspiradoras mitológicas de las tareas intelectuales, ya no trata tanto de los héroes y los dioses, ni de deleitar con historias asombrosas y fantásticas, como de llevar a cabo una labor de cronista, acerca de las causas de las Guerras Médicas, que enfrentaron a griegos y persas (medos). Todavía Heródoto no se distancia totalmente de los relatos tradicionales y encuentra una cierta verosimilitud en las leyendas sobre el origen de la Guerra de Troya, mezclando muchos otros relatos míticos con su labor historiográfica. Su Proemio reincide en la novedad abierta por Hesíodo al reivindicar la auto-

2 Heródoto Historia. Editorial Gredos. Traducción y notas de Carlos Schrader. Libro I-II. Madrid 1977.

3 1. Clío (Musa de la Historia); 2. Euterpe (Flauta); 3. Talía (Comedia); 4. Melpómene (Tragedia); 5. Terpsícore (Danza); 6. Erato (Lírica coral); 7. Polimnia (Pantomima); 8. Urania (Astronomía); 9. Calíope (Épica). 
ría del relato: "Ésta es la exposición del resultado de las investigaciones de Heródoto de Halicarnaso para evitar que, con el tiempo, los hechos humanos queden en el olvido y que las notables y singulares empresas realizadas, respectivamente, por griegos y bárbaros - y, en especial, el motivo de su mútuo enfrentamiento- - queden sin realce». Tenemos en la Historia de Heródcto la primera obra extensa que se escribió en prosa griega, comparable en magnitud a los poemas épicos homéricos. Heródoto era consciente se ser un continuador de la épica al tiempo que se daba perfecta cuenta de que sus objetivos se desplazaban desde la magnificación poética de los relatos tradicionales sobre dioses y héroes hacia la cronica histórica de los hechos humanos.

La Ilíada narraba el enfrentamiento mítico entre griegos y asiáticos que nuestro historiador toma como precedente a su labor, más cercana. Su obra comienza dando crédito al rapto de Helena por los troyanos como origen de las disputas entre griegos y bárbaros, precedido por el aún más mítico rapto de $f_{o}$ (L.I, 1-5). Concede, pues, verosimilitud a las leyendas acerca del rapto de mujeres como causas de las contiendas antiguas, ya considerando lo que de ello contaban los persas (L.I, 1-5) como lo que le narraron los sacerdotes egipcios (LII,113-120). Y si bien puede apreciarse en la tradición del rapto de mujeres un motivo de contiendas en una remota época prehistórica, la Guerra de Troya se situaría ya en un estadio superior, no pudiéndose aceptar, como hace Heródoto, tal causa, como motivo del primer enfrentamiento multitudinario entre los dos pueblos.

Tucídides ${ }^{4}$, es realmente quien representa el nacimiento de la Historiografía. Más allá de los residuos míticos de Heródoto, se enfrentará críticamente con la tradición de los poetas y nos ofecerá una fiel crónica del enfrentamiento entre atenienses y espartanos. Así, comienza su Historia de las Guerras del Peloponeso desconfíando de las narraciones tradicionales sobre la Guerra de Troya, señalando que Homero vivió mucho después de dicha contienda (I,3), que los griegos aún no estaban unidos ni firmemente establecidos, dedicándose a la piratería y al nomadismo, que el arte de la navegación debió de estar muy pobremente desarrollado y que, por consiguiente, la trifulca de Troya se debía a otros motivos distintos de los cantados por los aedos:

4 Tucidides Historia de la guerra del Peloponeso. Biblioteca clásica Hernándo. Introducción traducción y notas de Francisco RoDRIGUEz ADRADOs. Tomo I, Libros I y II. 2.a edición, Madrid 1967. 
«Agamenón organizó la expedición porque era más poderoso que sus contemporáneos y no porque los pretendientes de Helena, a cuyo frente fue, estuvieran obligados por el juramento prestado a Tindareo" ${ }^{5}$ (I,9). Dicha expedición, se nos dice, fue la primera cosa en común que hicieron los griegos y la más grande empresa militar hasta su tiempo, pero no más que una escaramuza $(\mathrm{I}, 10)$, comparándola con las fuerzas que se pondrían en juego en la muy posterior Guerra del Peloponeso, que el historiador Tucídides nos narra como cronista contemporáneo a la misma. De la contienda antigua «se demuestra por los hechos que fueron inferiores a la fama y a la tradición que, debido a los poetas, se ha impuesto acerca de ellos» (I,11).

Cuando Tucídides intenta narrar los hechos históricos se encuentra como principal impedimento, las muchas mistificaciones forjadas por los poetas $y$ creidas por el pueblo: «Esto es lo que he averiguado sobre los acontecimientos del tiempo antiguo, para cuya aceptación son difíciles de hallar pruebas terminantes, pues los hombres aceptan unos de otros sin pruebas e indistintamente las tradiciones de los sucesos antiguos, aunque sean de su propio país... Otras muchas cosas de hoy en día y no olvidadas por el tiempo las creen también erróneamente los demás griegos... Tan carente de molestias es para los más la búsqueda de la verdad y con tanta preferencia se vuelven hacia lo primero que se presenta" $(I, 20)$.

Tras la constatación de que resulta más fácil creer los relatos fabulosos que la investigación racional de las verdaderas causas de los acontecimientos humanos, se nos insta a preferir lo verdadero a lo agradable, los relatos que aportan pruebas o dan razón de sus contenidos a los que carecen de dichas garantías: "Sin embargo no se equivocaría el que creyese que las cosas que conté, a juzgar por las pruebas citadas, eran así poco más o menos, y no diese fe más bien a lo que han cantado acerca de ellas los poetas, adornánelolas para engrandecerlas, ni a lo que los logógrafos escribieron, tendiendo más a lo agradable de oir que a la verdad; cosas sin pruebas y las más llevadas al terreno de la fábula de una forma increible por el mucho tiempo que hace que sucedieron» $(I, 21)$.

Y ya refiriéndose a la guerra entre Atenas y Esparta de la que él, como contemporáneo, se va a ocupar de registrar fielmente para la posteridad, señala sus

Padre de Helena del que se dice que hizo jurar a los pretendientes de ésta (caudillos luego en la guerra contra Troya) que defenderían siempre al elegido, que sería Menelao, hermano de Agamenón y rey de Lacedemonia (Esparta). 
dificultades de indagación y la carencia de adornos de su prosa peculiar: «La verdad fué hallada con trabajo, porque los testigos de cada suceso no decían lo mismo acerca de las mismas cosas, sino de acuerdo con las simpatías o la memoria de cada uno. Para una lectura pública, la falta de color mítico de esta historia parecerá un tanto desagradable; pero me conformaría con que cuantos quieran enterarse de la verdad de lo sucedido y de las cosas que alguna otra vez hayan de ser iguales o semejantes según la ley de los sucesos humanos, la juzguen útil. Pues es una adquisición para siempre y no una obra de concurso que se destina a un instante" (I,22).

Después de que la periferia del mundo helénico produjese a los presocráticos, a Heródoto y a los sofistas, tres atenienses, un filósofo, un estadista y un historiador (Sócrates, Pericles y Tucídides), darían gloria a Atenas con sus acciones y obras. No es casual que todo el movimiento intelectual del mundo griego culminase en el invento y desarrollo de una fórmula inédita de gobierno, que nos recuerda el propio Tucídides al transcribir un famoso discurso de Pericles, en el que el gran gobernante de Atenas se expresaba de la siguiente manera: "Tenemos un régimen de gobierno que no envidia las leyes de otras ciudades, sino que más somos ejemplo para otros que imitadores de los demás. Su nombre es democracia, por no depender el gobierno de pocos, sino de un número mayor» (II,37).

Ya Ovidio, que está situado en medio del comienzo del tránsito de la era antigua a la era cristiana (s.I a.C.-I d.C.), será plenamente consciente de la distancia entre el mito y la historia, de ahí que los mitos de sus Metamorfósis no sean ya relatos religiosos con pretensiones de veracidad sino cuentos y fábulas con sentido didáctico a través de los cuales se pretende deleitar y enseñar. Por eso al comienzo de su Arte de Amar nos dice: "No mentiré diciendo, Febo, que tú me has dado estas artes, ni tampoco un ave celestial me adoctrina con su canto, ni se me han aparecido Clio y sus hermanas mientras apacentaba rebańos en tus valles, Ascra ${ }^{6}$; es mi propia experiencia la que me inspira esta obra: haced caso, pues, a un poeta experto; cantaré la verdad" (L.I,25-31).

Parecería que la constitución de la historiografía habría de dejar, como la filosoffa, un lugar seguro y permanente para la reflexión segura y distinta, pero

6 Alusión a Hesíodo, que fue a quien las Musas se le aparecieron en Ascra, donde pastoreaba, otorgándole el don de la inspiración, entendida como arte de decir la verdad y no, como aquí, en Ovidio, como mero tropo con el que el poeta indica que quiere poner en juego toda su habilidad y sus capacidades (Cfr. Theog. 22 ss.). 
siguiendo las aporías que la idea de escritura verdadera suscitaron ya en los pensadores clásicos, desatendiéndose hasta la contemporaneidad, veremos que el panorama actual es muy otro.

\section{Los orígenes griegos de Occidente: De la oralidad a la escritura}

La civilización Occidental se asienta sobre las producciones del pueblo griego arcaico, clásico y helenístico. Pero sobre la poesía épica colectiva de Homero, las composiciones de Hesíodo, la Historia, la tragedia y luego la comedia, se yergue la Filosofía, excepcionalmente la de Platón y Aristóteles, como la esencia de nuestro ser Occidentales.

En la épica arcaica el poeta relata una serie de gestas a las que atribuye valor histórico (veracidad) por haberlas presenciado en persona (Homero Odisea, VIII, 488ss), o por haber recibido inspiración de un dios, casi siempre la Musa (Iliada, II, 484ss; Od. XII 189ss; Hesíodo Teogonía 22ss), con las que pretende procurar el deleite, la piedad y la educación. Su recitación constituía para la nobleza una forma de levantar el ánimo (Iliada,IX,185ss) y recrearse, y para el pueblo, un modelo a seguir. Como dice E.A.Havelock en expresión afortunada Homero fue la Enciclopedia tribal de los griegos, un "arquetipo épico de la palabra preservada por medios orales" que «se componía de un compendio de materia a recordar, de tradiciones a mantener y de paideia que transmitir» ${ }^{7}$.

El aedo de la Grecia arcaica es un poeta iletrado que improvisa sus poemas acompañado de un instrumento de cuerda ${ }^{8}$. No repite de memoria un texto aprendido, como los poetas posteriores, como Ión de Efeso, por ejemplo, el interlocutor de Sócrates en el diálogo platónico que lleva tal nombre, sino que domina ciertas técnicas tradicionales de improvisación (sistemas formulares) que le permiten componer poemas sin ayuda de la escritura, como bien ejemplifican los aedos Femio y Demódoco en la Odisea. Ión ruega la inspiración para recordar lo leído, para que no le falle la memoria reexpositiva, mientras que el rapsodo antiguo pide a la Musa que le ayude a improvisar, para que no le falle la memoria recreativa, aquella que, basándose en un núcleo fundamental

7 Eric A. HAvelock Prefacio a Platón. Ed. Visor. Madrid 1994, pág. 59.

8 "Al principio, habiendo nacido de la improvisación tanto la tragedia como la comedia". ARISTÓteles Poética (1449a). 
(mitema, fórmula), es capaz de recrearlo con infinitas variaciones, introducidas espontáneamente y sobre la marcha, por medio de la improvisación.

En Homero la escritura sólo es aludida una vez y con tintes siniestros, es calificada tanto de mortiferos signos (semata lygra) como de malvados signos (sema kakón) (IliadaVI,168 y 178), con los que se ordena la muerte del portador analfabeto de un mensaje, en el que va escrita su sentencia condenatoria. La resistencia del pueblo griego a la escritura y los datos de mitología comparada, que han confrontado las tradiciones orales arcaicas con las actuales, junto a las peculiaridades del rapsodo arcaico, permiten rechazar la tesis de un texto prefijado y repetido de memoria. Los poetas recitaban, con gran uso de la improvisación los poemas tradicionales, en las lujosas casas de la aristocracia, en los festivales religiosos (entre los que se contaban los certámenes atléticos), en los funerales y en los actos de carácter político. Lo que hacen Homero y Hesíodo es ulevantar acta del uso público y de las costumbres privadas de todos, hombres y dioses" ?.

El paso de la naturaleza a la cultura, en cuanto considerado particularmente en su aspecto de tránsito desde una sociedad oral a otra en la que se usa la escritura, se revela como una hipótesis antropológica reduccionista y errónea, si se considera dicho tránsito como superposición y extinción de la primera por la segunda. Tal idea puede ser mantenida mientras la consideremos relativa al predominio de una tendencia sobre otra, de manera que podamos hablar de unas sociedades y épocas en las que ha predominado la cultura oral sobre la cultura escrita y viceversa, excepto en los casos de inexistencia de la escritura, que son eminente y evidentemente de plena oralidad.

En el tiempo de Platón, por ejemplo, la tensión entre las dos tendencias se encuentra rota. Platón atribuye a los poetas ula condición de medios vehiculares de la educación griega" y precisamente "lo que él pretende es solucionar una crisis de su época, y ello lo tiene plenamente ocupado, porque su propósito estriba en ponerse en el lugar de los poetas" ${ }^{10}$ y en poner a la filosoffa, en el lugar de la poesía. Él será uno de los que se encargará de inclinar la balanza hacia la cultura escrita enfrentándose con la cultura oral. Pero debemos tener siempre presente que el predominio de una tendencia sobre la otra nunca supone la desapari-

9 HAVELOCK op. cit. pág.75.

10 HAVELOCK op. cit. pág. 101. 
ción de la vencida sino su despotenciación, ya que nosotros mismos, en nuestra contemporaneidad escrita, no dejamos de estar sujetos, también a la oralidad.

La época heroica que reflejaba oralmente la poesía arcaica griega, hasta ser después parcialmente puesta por escrito, se caracteriza frente a las demás épocas, por la intervención de los dioses en los asuntos humanos y el endiosamiento de los propios héroes. Los dioses estaban más cerca de los hombres, al tener, además de forma antropomórfica, un buen número de cualidades humanas (amor, celos, odio, alegría, cólera, pasión, envidia, piedad, etc); y los hombres, estaban más cerca de los dioses, al tener los mejores, ciertas cualidades divinas especialmente respetadas (poder, gloria, fama, riqueza, belleza, sabiduría, etc) y ser teomórficos. La diferencia fundamental entre ambos: los dioses son felices e inmortales, los hombres desgraciados y mortales. Pero hay excepciones, como el castigo de los dioses: Prometeo, Tántalo, Sísifo, o el sufrimiento que se causan entre ellos por rivalidad.

La felicidad homérica es distinta de la felicidad de los filósofos. Los dioses homéricos pueden ser felices y al mismo tiempo despiadados, crueles, libertinos, a tal idea amoral de felicidad arcaica consistente en belleza, poder e inmortalidad, una idea que concibe el poderse permitir los excesos e injusticias como parte de la felicidad, (de ahí que el dios más poderoso, Zeus, sea el más feliz, y en ocasiones el más libertino, despiadado y caprichoso), se opondrán Platón y Aristóteles. Tan solo algunos sofistas, como Gorgias y Trasímaco, recogerán la idea homérica de felicidad al hacer equivalentes la justicia, la sabiduria, la belleza y la felicidad a la fuerza. A éstas equivalencias se enfrentará la socrático-platónica que equiparará justicia, conocimiento, bien, belleza y felicidad. A la máxima homérica: la virtud es poder; se opone la socrática: virtud es conocimiento. Pero ya entre los poetas (Ṕ́ndaro, Jenófanes) se había dado una crítica a los excesos de los dioses o a la impiedad que llegó a suponer la antropomorfización de la mitología.

Habría que encajar la utilización de los mitos que hace Platón, empleo narrativo de alegorías poéticas con el fin de transmitir conocimientos, mentiras necesarias del estadista, como los llamará en La República ${ }^{11}$, con su enfrentamiento a la poesía. Una forma de hacerlo es bajo la idea de que se están utilizando las armas del enemigo, del mismo modo, que en nuestra época, el ateismo marxista utilizó la forma catecismo para dar publicidad a su movimiento.

11 Cfr. Platón República: 389b-c; 414b-d; 459c-460a; 460e-461a; 463d. 
Los cristianos han sentido en muchos momentos a Platón como un precursor. Este ateniense, que había querido escribir tragedias, por un extraño destino, prepara el cristianismo con la difusión de las religiones orientales. Más los filósofos no son consecuentes con la uniformidad que se quiere ver en ellos, y así, Platón, se empeńó teórica y prácticamente en construir una ciudad, una comunidad racional de hombres en solidaria convivencia, donde los esfuerzos por realizar una política justa y racional, necesitaban de ilusiones que ayudasen a promover el orden ideal establecido. De ahí la inconsecuencia entre Razón y Mito, Filosofía y Poesía, en la obra platónica, de ahí la incongruencia entre el Estado perfecto y racional que procura la felicidad terrenal y el mito ultraterreno de Er con que finaliza la República.

Sócrates conceptualiza pero no escribe y nos presenta el reto del filósofooral, con lo cual, vemos que conceptualización no equivale a escritura y que es posible un pensador que no haga uso de ésta. Platón escribe diálogos, lo que ya constituye un atrevimiento, porque el diálogo es un vehículo eminentemente oral. Pero parece que la escritura se le mostró a Platón imprescindible para progresar en la conceptualización y en el desarrollo del pensamiento abstracto, no siendo los recursos de la oralidad aptos para la transmisión de la Filosofia.

La escritura se irá lentamente convirtiendo en aliada de la Filosofia, de su mano, los sofistas y los filósofos desplazarán a los poetas como educadores del pueblo griego. Los Diálogos de Platón están traspasados por esta tensión de la lucha final por la competencia educativa y el propio pensador, que encarnaba el paso definitivo en la Grecia clásica de la oralidad a la escritura, dejó un monumento literario en el que se refleja el desgarramiento de quien se cuestiona su tradición junto a la ambigüedad con que es recibida toda novedad en la cultura.

\section{Platón entre el Mythos y el Lógos. Filosofia y escritura en el paso de la naturaleza a la cultura}

Como ha señalado Emilio Lledó Platón es el introductor de la forma del diálogo en la composición escrita ${ }^{12}$, la fórmula propia de la oralidad socrática, el diálogo, que ya está rompiendo con la estructura oral de la transmisión del

12 Platón Diálogos. Ed. Gredos. Vol. I. Madrid 1985. "Introducción general» por Emilio LLEDO IÑIGo, pág. 11. 
mito como vehículo socializador por excelencia, es traspasada a la escritura, lo que no dejaría de tener importantes efectos. De la Filosofía poético-litúrgica de los presocráticos que ya se separaba de la oralidad épico-poética de Homero se pasará a la oralidad dialéctica de Sócrates, que terminará convirtiéndose en la escritura dialéctico-filosófica en Platón, inspirada en la matematización geométrica. La democratización del Logos en el diálogo rompía con el lenguaje dogmático, pero forzada por los sofistas a la inseguridad, tuvo que buscar la corrección racional de la geometría, para no encaminarse hacia la arbitrariedad de la retórica y encauzar la búsqueda de la racionalidad política.

Gran parte del Crátilo, exceptuando los lugares donde Platón mantiene un poco de seriedad, (de los que hablaremos a continuación), resulta una parodia insufrible, con la que Platón, hace que Sócrates represente el descalificativo papel de sofista y basándose en sutilezas etimológicas exageradas, con retazos de verosimilitud, demuestre que, tales métodos, de la peor sofistica, (representados en otro diálogo por Eutidemo y Dionisidoro), pueden persuadir y hechizar a los ignorantes como Hermógenes, (su cazurro interlocutor, que no reacciona ni ante las ironías más violentas), pero no sirven para mucho más. Ya en el Protágoras (Cfr. 339a ss) demostraba Sócrates que las sutilezas hermenéuticas ingeniosas, que despliega interpretando un poema de Simónides, no llevan a ninguna parte, lo que es bien acogido en esa ocasión, una de las pocas veces en las que el filósofo se encuentra frente un interlocutor de su misma envergadura.

Según Proclo, la doctrina del origen convencional del lenguaje aludida por Hermógenes al comenzar el Crátilo platónico, (en contraposición a la teoría naturalista de quien da nombre al diálogo), pertenecía a Demócrito ${ }^{13}$. Sócrates se enfrenta con ambas teorías (convencionalista y naturalista) del lenguaje al hacer admitir a sus interlocutores que se puede "hablar falsamente" (Crát.385b; cfr.Eutidemo 286b-c y Sofista 251 a-b). Eso significa que hay dos clases de discursos, el verdadero que es capaz de designar lo que es y lo que no es, y el falso, que es incapaz. Lo que Sócrates, cometiendo un paralogismo, aplica a los nombres.

De todas formas, la corrección platónica a ambas teorías se mantiene. El lenguaje, los nombres que aplicamos, no son naturales o convencionales, sino 
que son en primer lugar, verdaderos o falsos. Lo verdadero será conforme a la naturaleza y lo falso conforme a la opinión, lo primero muestra lo que es, siempre lo mismo, lo segundo lo que parece, distinto para cada cual (cfr. Crát. 386e-387a). Con el nombre (verdadero) distinguimos las cosas tal como son, siendo entonces el lenguaje "un cierto instrumento para enseñar y distinguir la esencia» (Crát. 388b-c). Un maestro (didáskalos) utilizará bien el lenguaje, conforme al oficio de enseñar, del mismo modo que cada profesional empleará bien el instrumento (órganon) que involucre su oficio (Crát.388c). La verdad será entonces una convención lingüística (nómos) acorde con la naturaleza (physis). Algo que no concuerda mucho con la imagen tradicional y escolar del platonismo.

Ahora bien, los nombres nos son proporcionados por el uso (nómos), siendo el legislador (nomothétes) el encargado de poner nombres (Crát. 388e-389a) a los objetos, fijándose en lo que es por naturaleza y en sí. El legislador, con los sonidos y las sílabas (materia), ha de formar el nombre naturalmente adecuado a cada cosa, fijándose en lo que es por naturaleza y en sí respecto del nombrar (forma), es decir, en el "nombre en sí» (Crát.389d). Mientras se atenga a esta misma forma, lo construido será correcto, aunque se empleen sílabas y sonidos distintos, como ocurre en las distintas lenguas de los distintos lugares de la tierra (Crát.390a). "Nada importa que sean unas u otras las letras que expresan el mismo significado ni tampoco que se añada o suprima una letra con tal que siga siendo dominante la esencia de la cosa que se manifiesta en el nombre" (Crát.393d). Los nombres pueden cambiar de fonemas pero significar lo mismo, a ésto, significar lo mismo, llama Platón «su virtud" (Crát.394c), la virtud de un nombre (esté compuesto de las letras que sean) consiste en manifestar la esencia de lo nombrado, lo que la cosa dicha es.

Quien va a juzgar la fabricación del legislador es el que sabe hablar, el que utiliza el lenguaje y por saber utilizarlo, es llamado dialéctico (Crát.390a-c). El legislador construye el nombre bajo la dirección del dialéctico, ya que "el nombre tiene por naturaleza una cierta exactitud" (Crát.391a-b). Pero el legislador antiguo ha podido equivocarse y no es provechoso mantenerse en el error, engañándose (Crát.436b), sino que conviene rectificar lo que no es adecuado a la esencia de lo nombrado, pues tiene esencia todo aquello que merece la predicación de ser (cfr.Crát.423e).

El diálogo gira entorno a la burla del devenir heracliteo asociado a la actitud etimologista y la crítica de las teorías rivales de Crátilo y Hermógenes por 
medio del esbozo de una teoría de la imitación para el lenguaje, expuesta por Sócrates, (como preludio de la idea posterior de participación), en la que se dice que "los nombres bien puestos son parecidos a los seres de los que son nombres y son imagen de las cosas" (Crát.439a). El lenguaje reproduce la realidad, la "cosa en sí» (Crát.439d) y es respecto de ésta que se tiene un criterio de corrección de los nombres. La culminación y finalización del diálogo reside en la constatación de que no existe aquello que nunca se mantiene igual, no existe el devenir, carente de esencia, sin ser ni llegar a ser nunca en sí, y que por tanto ni siquiera puede ser conocido por nadie (cfr. Crát. 439e-440c). En contra de Platón y completando los estudios que Crátilo dejó prometidos a Sócrates, un cierto conocimiento (paradójico) del lenguaje en devenir (investigación de la paradoja), será abordado en nuestra época por Gilles Deleuze y por todos los interesados en aquello que se sustrae al ser y a la apropiación.

Contra la tesis de la doctrina no escrita de Platón y la reserva del saber socrático expuesta, con diferencias, por investigadores como Cornford, Szlezák y Tovar ${ }^{14}$, entre otros, vemos también aquí que, Sócrates, al igual que en numerosas ocasiones, no se guarda su saber, burlándose con ironía del secretismo y las conversaciones privadas (cfr.Crát.413a) sino que investiga en compaña, sin saber de antemano a dónde va a llevarle la investigación (cfr.Crát.391a-b).

Lo mismo podría decirse de la escritura platónica y del escribir en general, pues si se conociese de antemano el resultado final de la investigación, el escritor se limitaría a poner las pruebas y las conclusiones, elaborando una sola obra y se evitaría todo el titubeante recorrido que lleva hasta la multiforme producción literaria.

Respecto a la Antigüedad, cinéndonos tan sólo al material escrito conservado, se puede decir con seguridad que, desgraciadamente, la mayor parte se ha perdido. Respecto a lo no escrito, podemos estar ciertos de que la totalidad ha desaparecido. Ya es dificil reconstruir el pensamiento de Esquilo sobre la base

14 F. M. CoRnford La filosofla no escrita. Ed.Ariel. Barcelona 1994. T. A. SzlezAK Leer a Platón. Ed. Alianza Universidad. Madrid 1997. A. Tovar Un libro sobre Platón. Ed. EspasaCalpe. Madrid 1973, cap. I, pág. 13: «Los venideros dudarán de que en los escritos de Platón esté lo más esencial de su pensamiento. Si él consideraba juego la actividad de escribir, ¿cómo no iba a ser algo más que escritor?. ¿Cómo no iba a dejar un logos vivo, una especie de llameante verdad, irreductible a la escritura, que fuera su más auténtico testamento?n. 
de que poseemos siete de las cien tragedias que escribió, (según registraron los filólogos alejandrinos), como para aventurarnos a reconstruir no sólo lo escrito y no conservado, sino incluso lo que nunca se llegó a escribir pero fue presumiblemente pronunciado. Con Platón, sin embargo, la aventura es abordable, gracias a que tenemos la suerte de haber conservado la mayor parte de su obra; y aunque no entendamos del todo lo escrito, o precisamente por eso, salimos en busca de lo no escrito pero pronunciado oralmente. Algún aventurero del conocimiento saldrá algún día en busca de lo no escrito ni dicho mas pensado por Platón, pero nosotros, más modestos, creemos que ya es suficiente con intentar clarificar el legado escrito, envuelto en no pocas controversias.

Es en el Fedro (274c-275b) donde se narra el clásico mito de la invención de la escritura. El dios Theuth se limita a explicar la utilidad de los inventos que ofrecía al rey Thamus de Egipto, quien les opone ciertos reparos. Pero siendo los inventos el número y el cálculo, la geometría y la astronomía, el juego de damas y de dados, y en especial, las letras; sólo éstas últimas son discutidas entre ambos. El dios ofrece la escritura como un antídoto contra el olvido, un fármaco para la memoria, sin embargo el rey estima que lo que proporciona no es más que un mero recordatorio para los hombres, un débil memorizador, que les hará desmemoriados, al fiarse de lo escrito en el exterior y no retener nada en el interior. Antonio Tovar recogía ésta ambigüedad en la que Platón situaba la escritura: «Nadie antes ha osado escribir en prosa tanta cantidad... Nadie antes que él ha hecho este uso de la escritura, como nadie antes que él ha medido el peligro de la letra escrita. Saber cosas porque uno las tiene apuntadas no es lo mismo que sabérselas a solas, en el recuerdo..., bien aprendidas. Día vendrá en que los hombres no sabrán nada porque entre todos lo tendrán todo almacenado, en los libros de sus bibliotecas» ${ }^{15}$.

Los dialogantes, Fedro y Sócrates, admitirán la objeción de Thamus, reseñando que sería ingenuo considerar que se deja establecido firmemente algo, por el hecho de ponerlo por escrito (Fedro 275c). La escritura nos dice cosas, pero si se le pregunta algo, contesta con el más altivo de los silencios, no elige el interlocutor y siempre necesita al padre para ser defendida (cfr. Fedro 275d-276e). Aqui se muestra la inferioridad del diálogo escrito sobre el hablado. Aunque también, puede interpretarse lo que sigue a continuación, como un elogio dirigido hacia otra clase de escritura, como bien apunta Emilio

15 A. Tovar, op. cit. cap. I, pág. 12. 
Lledo ${ }^{16}$, precisamente la platónica, reflejo de la palabra oral. Teoría de la participación, en la que el diálogo escrito participa del diálogo oral, reproduciendo sus efectos, más allá del arte imitativo (mímesis) de los poetas, con la cual, Platón, logrando escribir dialécticamente, siembra una semilla inmortal que fructificará en la posteridad; escribiendo con palabras capaces de ayudarse a sí mismas y de generar en el lector el discurso interior del pensamiento ${ }^{17}$.

Vemos, por tanto, que la reflexión ofrecida sobre la escritura es ambivalente, condena lo escrito respecto a lo oral y al mismo tiempo, nos habla de un poder especial de la escritura que reúna los requisitos de la dialéctica. "El argumento central del mito es la memoria... Dos formas de cultura frente a frente. Por un lado la cultura de la oralidad, sujeta al tiempo inmediato de la vida, de los latidos; por otro lado la cultura de la literalidad, que, como un eco de lo dicho, sostiene el aire semántico en un rasgo de escritura, en una señal para los ojos. La cultura del oído, de la voz, camino de la cultura de la vista, de la ideas ${ }^{18}$. La temporalidad inmediata se transforma en temporalidad mediata que pemanece más allá de su tiempo. La escritura de Platón "tiene sentido sin su autor" ${ }^{19}$ siempre y cuando se encuentre, con la mirada de un lector, que se esfuerce en restituirle su sentido.

En el Fedro se presentan los inventos de la matemática y la escritura como dos novedades heterogéneas, sin embargo la matemática también es escritura y la escritura platónica pretende ser matemática. El afán de objetividad científica para las disciplinas humanísticas impregna toda la historia de Occidente. Desde la relativización antidogmática de las ciencias a modelos perfeccionables, revisables y adecuados para un determinado periodo de la historia, hasta su quedar obsoletos o englobados dentro de una teorla más integradora y eficaz, se han acercado más que nunca. El espacio del discurso platónico es el lógos, sus límites, a menudo alcanzados, el escepticismo y la mística. De ahí que la historia del platonismo oscile entre los límites de Platón, situándose en el primero un Arcesilao, un Plotino en el segundo, sin tener en cuenta que no es en los extremos sino en el interior del discurso en el que se encuentra la filo-

16 Platón Dialogos. Ed. Gredos. Vol. III. Madrid 1986. Fedro, cfr. nota n. ${ }^{\circ} 170$.

17 Cfr. Fedro 276e-277c; Teeteto 189e; Sofista $263 \mathrm{e}$.

18 Emilio LLEDO El silencio de la escritura. Centro de Estudios Constitucionales. Madrid 1992. (El capítulo 5 es un detallado comentario del Fedro). Cap.5, aptdo 1, pág. 113-114. (En sus análisis Lledó sigue a Gadamer).

19 Ibid. Cap. 5, aptdo 3, pág. 121. 
sofía. Esta siempre ha oscilado entre el dogmatismo que lo sabe todo y el escepticismo que no sabe nada, para acabar afirmando que se sabe algo, un poco más o un poco menos, mas no todo ni nada.

4. El poder de la escritura: Lévi-Strauss y el aprendiz de brujo de los nambiquara

Los nambiquara, aborígenes del Brasil a quienes se dedica el capítulo 28 de Tristes trópicos, que son analfabetos, comienzan a imitar a Lévi-Strauss realizando líneas onduladas con papel y lápices proporcionados por el antropólogo. Pero "el jefe», quien, "sin duda era el único que había comprendido la función de la escritura" ${ }^{20}$, es el que pide una libreta de notas. Desde entonces no comunica inmediatamente las informaciones al etnógrafo sino que primero realiza una comedia de imitación de la escritura, en la que finge leer.

$\mathrm{Al}$ realizar el intercambio de presentes con el hombre blanco, el jefe finge de nuevo leer en su libreta, como si en ella estuviese estipulado lo que correspondía dar y recibir a cada cual. Ello le permite adoptar un rol imprescindible frente a los suyos, al persuadirles de que las mercancías habían de pasar por su mediación. Con ello vemos ya dos caras de la escritura. En primer lugar el surgimiento de la figura del intermediario, que afianza con ello su situación de poder y privilegio. En segundo pero en el mismo lugar, se presenta la figura del juez o árbitro imparcial, representado no por el sujeto agente, sino por las líneas sinuosas del papel, que estipulan objetivamente.

La escritura como inventario, supone un modo de estimación objetiva de las mercancías en el intercambio, idea que, nos comunicará el antropólogo, les es totalmente extraña a los nambiquara ${ }^{21}$. Una forma de evitar las situaciones de descontento en las transacciones que suelen acabar en conflictos armados entre los grupos de individuos, «las guerras no suelen tener otro origen" ${ }^{22}$-nos dirá Lévi-Strauss-; lo que nos mostraría un aspecto benéfico de la escritura ignorado por los comentarios de Lévi-Strauss. Aspecto que se remite a ella enten-

20 Claude Lévi-Strauss Tristes trópicos. $\left(1 .^{2}\right.$ ed. 1955) Ed. Paidós Barcelona 2." edición espafiola 1992, pág. 321. (Citaremos TT).

21 TT. op. cit. cfr. pág. 327.

22 TT. op. cit. pág. 328. 
dida como geometría platónica, como medio de dirimir ecuánimemente los conflictos generados por el trueque. No obstante, éste último, aunque desigual, también deja de lado a menudo los enfrentamientos, como pudo comprobar el antropólogo al ver dos tribus hostiles apaciguarse mediante las donaciones recíprocas; lo que supone que de cualquier manera, "el conflicto deja lugar al mercado" ${ }^{23}$, contraponiéndose la guerra al comercio, la apropiación indebida al cambio recíproco de valores de uso.

Con la escena del intercambio en la que el jefe finge leer, «la escritura había hecho su aparición entre los nambiquara; pero no al término de un laborioso aprendizaje, como era de esperarse. Su símbolo había sido aprendido, en tanto que su realidad seguía siendo extrańa. Y esto, con vistas a un fin sociológico más que intelectual. No se trataba de conocer, de retener o de comprender, sino de acrecentar el prestigio y la autoridad de un individuo $\longrightarrow$ de una función-a expensas de otro. Un indígena aún en la Edad de Piedra había adivinado, en vez de comprenderlo, que el gran medio para entenderse podía por lo menos servir a otros fines. Después de todo, durante milenios, y aún hoy en una gran parte del mundo, la escritura existe en sociedades cuyos miembros, en su gran mayoría, no poseen su manejo" ${ }^{24}$. La realidad de la escritura entendida como medio intelectual, como forma de conocer, de retener o de comprender, entra en contradicción con aquello que simboliza, su función es ambigüa. La escritura en cuanto vehículo intelectual se enfrenta a la escritura como medio de dominación. Y así, el jefe de la tribu, era capaz de fingir la función escrita, mas incapaz de realizar y codificar el cálculo de estimación objetiva de los intercambios. El fenómeno de los escribas en un colectivo analfabeto que los utiliza, va ligado a una posición de poder, en tanto que el mismo individuo reúne con frecuencia las funciones de escriba y usurero dentro del colectivo; como en las aldeas de las colinas de Chittagong en el Pakistán, de las que habla Lévi-Strauss, donde el escriba usurero res, doblemente, quien domina a los otros" ${ }^{25}$. De ser capaz de estimación escrita en un medio analfabeto, el escriba-usurero podrá realizar el cálculo objetivo, pero engañará a quienes no pueden repetir y comprobar el proceso, guardándose para sí mismo la porción más grande en el reparto al estimar de forma subjetiva y egoísta que le corres-

23 TT. op. cit. pág. 327.

24 TT. op. cit. pág. 322.

25 TT. op. cit. pág. 323. 
ponde la mayor parte. Para que la estimación escrita no esté sujeta a fraude es necesaria la intersubjetividad, que todos los afectados puedan repetir el proceso con el mismo resultado. Los lenguajes técnicos jurídico-administrativos o científicos y no digamos los filosóficos, al no expresarse en forma coloquial, hurtan al colectivo sus pasos y reivindican una posición de privilegio y de poder.

La escritura es un medio que induce en un primer momento a la visión opuesta a la crítica que se le hace en el Fedro platónico: "La escritura es una cosa bien extraña. Parecería que su aparición hubiera tenido necesariamente que determinar cambios profundos en las condiciones de existencia de la humanidad; y que esas transformaciones hubieran de haber sido de naturaleza intelectual. La posesión de la escritura multiplica prodigiosamente la aptitud de los hombres para preservar los conocimientos. Bien podría concebírsela como una memoria artificial cuyo desarrollo debería estar acompañado por una mayor conciencia del pasado y, por lo tanto, de una mayor capacidad para organizar el presente y el porvenir. Después de eliminar todos los criterios propuestos para distinguir la barbarie de la civilización, uno querría por lo menos retener éste: pueblos con escritura, que, capaces de acumular las adquisiciones antiguas, van progresando cada vez más rápidamente hacia la meta que se han asignado; pueblos sin escritura, que, impotentes para retener el pasado más allá de ese umbral que la memoria individual es capaz de fijar, permanecerían prisioneros de una historia fluctuante a la cual siempre faltaría un origen y la conciencia durable de un proyecto... Sin embargo, nada de lo que sabemos de la escritura y su papel en la evolución humana justifica tal concepción" 26 .

Para Lévi-Strauss, uno de los periodos más creativos de la historia de la humanidad, donde se incluyen la agricultura, la domesticación de animales y otras artes, corresponde a la revolución neolítica, que se realizó sin el concurso de la escritura. Esta no se podrá ver como condición del desarrollo neolítico sino, a lo sumo, como una consecuencia lejana del mismo. "En el neolítico, la humanidad cumplió pasos de gigante sin el socorro de la escritura; con ella, las civilizaciones históricas de Occidente se estancaron durante mucho tiempo. Sin duda, mal podría concebirse la expansión científica de los siglos XIX y XX sin la escritura. Pero esta condición necesaria no es suficiente para explicar el 
hecho" ${ }^{27}$. Marx ya distinguió entre la cooperación preneolítica y la cooperación (expropiada) capitalista, adhiriendo a la primera la idea de propiedad común de las condiciones de producción y a la segunda su pertenencia a una clase privilegiada ${ }^{28}$.

El surgimiento de la escritura hacia el tercer o cuarto milenio antes de nuestra era va ligada a la "formación de ciudades y de imperios» ${ }^{29}$, a «la integración de un número considerable de individuos en un sistema político" ${ }^{30} \mathrm{y}$ con ello, a una eficaz distribución vertical de las sociedades, a la "jerarquización en castas y clases" ${ }^{31}$. La estructura piramidal de las sociedades, no obstante, también existió con anterioridad a la escritura, sostenida por otros medios de sujeción (orales), pero aquí lo fundamental es darse cuenta de cómo la escritura entró a formar parte de los recursos de dominación de las culturas humanas, sirviendo de apoyo, por ejemplo, a la religión, que pasa a codificarse, y al Estado, al control de los subyugados, que pasan a cuantificarse.

«Tal es, en todo caso, la evolución típica a la que se asiste, desde Egipto hasta China, cuando aparece la escritura: parece favorecer la explotación de los hombres antes que su iluminación. Esta explotación, que permitía reunir a millares de trabajadores para constrenirirlos a tareas extenuantes, explica el nacimiento de la arquitectura... Si mi hipótesis es exacta, hay que admitir que la función primaria de la comunicación escrita es la de facilitar la esclavitud. El empleo de la escritura con fines desinteresados para obtener de ella satisfacciones intelectuales y estéticas es un resultado secundario, y más aún cuando

27 TT. op. cit. pág. 324.

28 Karl MarX El Capital Libro I. Sección IV. Capítulo XI: La Cooperación. "La cooperación en el proceso de trabajo, tal como la encontramos, de manera predominante, en los comienzos de la civilización humana, entre los pueblos de cazadores-recolectores o por ejemplo en la agricultura de entidades comunitarias indias, se funda por una parte en que 'las condiciones de producción son de propiedad común'; por otra en que el individuo, singularmente considerado, está tan lejos de haber cortado el cordón umbilical que lo liga a la 'tribu' o a la 'entidad comunitaria', como la abeja individual de haberse independizado de la colonia que integra. Ambas cosas distinguen a esa cooperación de la capitalistan.

29 TT. op. cit. pág. 324. En el heládico reciente, alrededor del s. XV a.C., en plena Edad de Bronce, es cuando se adaptó el griego a la técnica de la escritura. Las tablillas cretenses en el sistema silábico Lineal B, obra de los escribas palaciegos de Cnosos, que llevaban las cuentas del imperio Micénico, asi lo atestiguan. Hecho que refuerza la tesis de la relación escritura-imperialismo.

30 TT. op. cit. pág. 324.

31 Ibid. 
no se reduce a un medio para reforzar, justificar o disimular el otro" ${ }^{32}$. Tenemos aquí planteada la teoría de la doble verdad característica de la hipocresía que ha teñido la política contemporánea. Los medios de dominación son presentados como elementos de liberación, de modo que la escritura oculta su carácter adverso y se presenta escolarmente como un inicuo placer estético, como un juego estético que puede estar encubriendo al intelectualismo orgánico. Lévi-Strauss nos ayuda a romper tal mitologia: "Si la escritura no bastó para consolidar los conocimientos, era quizás indispensable para fortalecer las dominaciones. Miremos más cerca de nosotros: la acción sistemática de los Estados europeos en favor de la instrucción obligatoria, que se desarrolla en el curso del s.XIX marcha a la par con la extensión del servicio militar y la proletarización. La lucha contra el analfabetismo se confunde así con el fortalecimiento del control de los ciudadanos por el Poder. Pues es necesario que todos sepan leer para que este último pueda decir: la ignorancia de la Ley no excusa su cumplimiento (sic)» ${ }^{33}$. La cultura de masas actual, no obstante, es doblemente oral y escrita, sujeta a la televisión, a la imagen que habla y al mismo tiempo, en cuanto alfabetizada, a la ideologización escrita, a la lectura de los periódicos y los best-sellers, a la acción de marketing sobre la conciencia burguesa de un capitalismo que ha traspasado la mera esfera de la reproducción material.

Desde esta perspectiva la Ilustración educativa, la instrucción obligatoria de los ciudadanos, revela que todo método de socialización es empleado, simultáneamente, como método de dominación. El sueño del total alfabetismo de las sociedades es un nuevo instrumento de poder, quizá no menos tenebroso que los mecanismos de la transmisión oral, pero al menos sí completamente novedoso respecto a las sociedades sin escritura y más omniabarcante. Pero el aumento del control social por los gobernantes no se debe solamente al empleo de la escritura, toda la tecnología y todo el desarrollo científico-técnico han contribuido a un mayor control, tanto ejercido contra la sociedad (p.ej.racionalidad instrumental del exterminio nazi) como a favor de ésta (p.ej.erradicación del virus de la viruela del planeta). El control social por tanto, es como la escritura misma, un Jano bifronte que nos lanza una paradoja terrible: no podrás inocular racionalidad política en oposición a la barba-

\footnotetext{
32 Ibid.

33 Ibid. (léase: incumplimiento)
} 
rie sin aumentar la codificación y el control social y con él, la posibilidad de predicción y planificación de las ciencias sociales, pero este último, abrirá al mismo tiempo la posibilidad de los mayores actos de barbarie.

A diferencia de los pueblos sin escritura (que utilizan otros mecanismos de dominación) en los pueblos en los que predomina la cultura escrita, la información impresa constituye uno de los principales elementos materiales de modelamiento de las conciencias y la herramienta de producción y mantenimiento de las ideologias, "accediendo al saber asentado en las bibliotecas, esos pueblos se hacen vulnerables a las mentiras que los documentos impresos propagan" ${ }^{34}$. Con la imprenta se propagan mentiras con apariencia de verdades, falsedades que, la manía revisionista del re-pensar los documentos transmitidos por la tradición, se ha propuesto combatir. Pero el proceso de desmitificación quizá es más lento que los mecanismos múltiples de producción de mitologías, con lo cual, pensando que vivimos en un mundo cada vez más racional, es posible que vivamos, por el contrario, en un espacio cada vez más mitologizado y que el mayor mito de nuestro tiempo sea, por tanto, el Mito de la Razón.

5. La escritura como simulacro: Gilles Deleuze y la lucha contra el 'Mito de la Razón'

Deleuze escribe en nombre propio tras la negación del yo y la crítica del sujeto, lo que supone que la escritura particular se convierta en despliegue de multiplicidades que atraviesan una encrucijada. Este nomadismo vuelve a contactar con las obras anónimas del pasado presentándonos una obra colectiva, producto de un individuo que es legión. El heraclitismo del que Platón se burlaba en el Crátilo, un trabajo sobre y desde lo múltiple en huida de lo monolítico y estable y de sus funestas consecuencias sociopolíticas, es reivindicado por el pensador francés.

El enfrentamiento contra la filosofía del Ser impregna toda su producción, en antagonismo con la imagen clásica y tradicional del platonismo, que se trata de invertir, al producir la diferencia y desvelar lo verdadero como fábula; resultando de ello, la verdad del simulacro, en cumplimiento con la tarea empren- 
dida por Nietzsche y legada para el futuro. En su Lógica del sentido ${ }^{35}$, nos muestra, que el sentido es una noción paradójica e inexistente ${ }^{36}$. Estudiando sus relaciones con el sin-sentido, se nos presentará a la paradoja, como límite de la violencia y de la dominación.

La dualidad más profunda que descubre Deleuze en Platón es la que se establece entre la oposición ser/devenir. Lo primero recibe la acción de la Idea, lo segundo se sustrae a la misma, se trata de la distinción copia/simulacro, donde lo segundo, en cuanto puro devenir, resulta inapropiable. "Incluso Platón llega a preguntarse si este puro devenir no podría tener una relación muy particular con el lenguaje: éste nos parece uno de los sentidos principales del Crátilos ${ }^{37}$. Un sentido irónico destinado a retirar el devenir del ámbito de lo pensable que Deleuze se toma en serio en vista de su rentabilidad subversiva. A un lenguaje de la solidificación en la Idea se contrapone un lenguaje de los acontecimientos, flujo del lenguaje en devenir rebelde capaz de esquivar el presente; una identidad infinita como trastocamiento de la identidad personal, como pérdida del nombre propio, como escepticismo o ausencia de saber. Dos facetas del lenguaje en general en la que una es recubierta por la otra, la positiva sujeta a la negativa, para ser destruida después, por la potencia de la negación absorbida, hasta llegar a la absoluta negación, esto es, al puro devenir. Esquema hegelianizante invertido que creemos ver en Deleuze, el gran negador de la dialéctica, que, sin embargo, puede que no lograse escapar de ella. Es posible que el estructuralismo tenga algo de dialéctico a su pesar.

"Lévi-Strauss indica una paradoja análoga a la de Lacán, en forma de antinomia: dadas dos series, una significante y otra significada, una presenta un exceso y la otra un defecto, por los cuales se remiten una a la otra en eterno desequilibrio, en perpetuo desplazamiento... el significante primordial es el orden del lenguaje; ahora bien, sin tener en cuenta el modo como se adquiera el lenguaje, los elementos del lenguaje han tenido que darse todos a la vez, de un golpe, porque no existen con independencia de sus relaciones diferenciales posibles» ${ }^{38}$. El significado en general es el orden de lo conocido, por encima

35 Gilles Deleuze Lógica del Sentido. Ed.Paidós. Barcelona 1994. Traducción del texto de Miguel MOREY, de los apéndices por Victor Molina. (A partir de ahora citaremos LS).

36 LS, cfr. Prólogo, pág. 23.

37 LS, ibid. pág. 26.

38 LS, Octava serie, «De la estructura», pág. 68. 
del cual coloca Deleuze la totalidad de la lengua o del lenguaje. Es sobre la serie significante previa que se organiza la serie significada, la ley se impone a priori y "este desequilibrio es lo que hace posible las revoluciones" ${ }^{39}$, porque la totalidad económica y política tiene que reajustarse en función de las partes que contiene. En este reajuste entre optimizador y optimizado caben las posturas reformistas, tecnocráticas y totalitarias, a diferencia de la actitud revolucionaria, que vive en el desajuste, en la distancia entre la totalidad social y la relación entre las series. Una actitud que se alimenta del significado flotante o símbolo siempre sobrante de la transacción, de lo que sobra en el exceso en una serie y lo que falta en el defecto de la otra.

El acontecimiento está inmerso en la estructura formada por dos series heterogéneas que "convergen hacia un elemento paradójico, que es como su diferenciante... el principio de emisión de singularidades" ${ }^{40}$, la casilla vacía que hace que el entramado funcione, el Aión en cuanto condición de posibilidad de Cronos. Esto implica la negación de la posibilidad de Totalización o plena optimización, como condición ontológica de la estructura, infinitamente deficitaria en sí misma. La totalización del Estado hegeliano, aquí quizá invertida, está destinada a romperse una y otra vez en una estructura que supura singularidades inapropiables. El aumento de la capacidad de optimización propia de la serie dominante en la estructura nunca será completo, lo cual no significa que no pueda haber una mayor o menor optimización dependiendo inversamente de la menor o mayor producción de singularidades.

En la inversión de Platón deleuziana la singularidad revolucionaria de la piel, la superficie, es el fondo y lo demás mera apariencia, es el lugar en el cual "el sinsentido y el sentido abandonan su relación de oposición dinámica, para entrar en la copresencia de una génesis estática, como sinsentido de la superficie y sentido que se desliza sobre ella» ${ }^{41}$. El enunciado que no es frase ni proposición apropiadora se sitúa en el lado del sinsentido que posibilita el nuevo sentido: Mallarmé, Artaud, Lewis Carroll, Joyce, Borges, F.S.Fitgerald, Malcolm Lowry, entre otros, con su literatura de la paradoja, hacen posible la literatura misma.

\footnotetext{
39 LS, ibid. pág. 69.

40 LS, ibid. pág. 70.

41 LS, Decimonovena serie, "El Humor", pág. 151.
} 
El lenguaje tiene una potencia vertida en varias dimensiones. "Son los acontecimientos quienes hacen posible el lenguaje" ${ }^{42}$, lo expresado es el requisito de la expresión, lo hablado es el efecto de superficie del lenguaje, que organiza las series divergentes de cuerpos y proposiciones desde la frontera que separa el hablar del comer haciéndolas converger en un punto paradójico, en una encrucijada que fue antes mal-llamada individuo. El verbo expresa un acontecimiento, el acontecimiento único del lenguaje, la univocidad indeterminada que "pone en contacto la interioridad del lenguaje con la exterioridad del ser» ${ }^{43}$. Lo primario no es el verbo ser, sino la verbalización, no es una acción sino una potencia, una capacidad latente.

Lo que separa, la superficie, posibilita. Deleuze se detiene en el entre de una serie de dualidades heterogéneas: la del hablar y comer, que hace posible las palabras, la de las proposiciones y las cosas, que posibilita la proposición, "lo expresado hace posible la expresión" ${ }^{44}$. Deleuze se detiene a continuación en un análisis postpsicoanalítico que parte de Mélanie Klein, para superar las mayores esnifadas de coca del fundador Sigmund Freud. Renunciamos a seguirle en esta serie. Retengamos tan solo la idea de continuidad entre lo que habla y lo que come, "entre esta boca y este cerebro es donde todo ocurre, duda y se orienta. Unicamente la victoria del cerebro, si se produce, libera la boca para hablar... y la alimenta una vez con todas las palabras posibles» ${ }^{45}$. Lo que antes se llamó alma se denomina ahora cerebro, el cuerpo antiguo es boca sexuada actual, el pensamiento es una conquista sobre el fantasma, una sublimación y por tanto, podremos decirlo también de la escritura, también sublimación.

Cuando esperamos que la verdad nos salga al encuentro desde el fondo de una página en blanco, lo que adviene es la escritura, retralda del fondo interno dionisíaco. Despedazamos con garabatos un papel para no despedazarnos a nosotros mismos. La escritura es una catarsis que quizá no tenga relación con verdad ninguna, excepto con la verdad de la catarsis. Del sinsentido que preside la lógica del sentido se desprende una noción de escritura que no es semilla inmortal como en Platón sino su noción inversa, esto es, excremento mortal, simulacro infundamentado, perecedero, inmerso en el devenir.

\footnotetext{
42 LS, Vigesimosexta serie, "Del Lenguaje», pág. 188.

43 LS, Ibid. pág. 191.

44 LS, Vigesimoséptima serie, "De la Oralidad", pág. 192.

45 LS, Trigésima primera serie, "Del pensamiento", pág. 226.
} 
Deleuze es un desmitificador que aplica sus instrumentos sobre el Mito de la Razón Occidental, subvirtiendo valores e invirtiendo perspectivas. «Invertir el platonismo significa entonces: mostrar los simulacros, afirmar sus derechos entre los iconos y las copias" " 4 . La escritura, el diálogo escrito de Platón, que es una copia degradada participante del dialogar oral, obtiene aquí su autonomía. Ya no necesita fundamento, puesto que el fundamentalismo de la razón dogmática se revela como la auténtica falsificación. En un mundo de simulacros que ya no admiten la hipocresía de esconder su condición, sino que la asumen con todas sus consecuencias, no hay fundamento de lo escrito.

La dialéctica platónica es entendida por Deleuze como una rivalidad entre pretendientes. «El mito, con su estructura siempre circular, es, ciertamente, el relato de una fundamentación" ${ }^{47}$. La mitologia, que antes hemos revelado como ilusión conveniente para el estadista, sería empleada por el filósofo de Atenas para aprovechar su potencial de fundamentación, resultando de ello, el aprovechamiento posterior de su potencia de dominación. La función del mito no es la clarificación del concepto sino la autentificación de la Idea y de la copia semejante o bien fundada.

Todos los Estados nacionales contemporáneos se yerguen sobre una mitología fundacional que se enseña en las escuelas como Historia, relato de las gestas heroicas de sus supuestos príncipes y generales, inventando una falsa continuidad. La pretensión de verdad de la Historia escrita de Occidente no es más que la autentificación de un pretendiente al imposible dominio universal, que hoy se manifiesta, en su máscara hipócrita, como la globalización capitalista. El ámbito de la representación que inaugura la filosofía platónica para Occidente pasa, de ser la representación filosófica fundamentadora y autentificadora del Estado, a desvelarse como la representación teatral del devenir, juego que había sido secuestrado y congelado hipócritamente en la máscara del Ser.

Para desesperación de sus críticos que le califican despectivamente de postmoderno, Deleuze, como Foucault, se concibe como Moderno y es más, radica en lo que Nietzsche denominó intempestivo ${ }^{48}$ tal condición: «Definimos la

46 LS, Apéndice I: "Simulacro y Filosofía Antigua», 1. "Platón y el simulacro», pág. 263.

47 LS, Apéndice 1.1, pág. 256.

48 Friedrich NIETZSCHE De la utilidad y de los inconvenientes de la historia para la vida (2.2 de las Consideraciones Intempestivas, escrita en 1873). Traducción española: Ediciones Península. Barcelona 1988, pág. 56: «sólo en cuanto pupilo de tiempos más antiguos, en particular de la 
modernidad por la potencia del simulacro" ${ }^{49}$. El simulacro oculta una potencia que destruye al pretendiente al original, "ya no hay punto de vista privilegiado ni objeto común a todos los puntos de vista" ${ }^{50}$. Ya no se trata de negar la diferencia sino de asimilarla, el triunfo del falso pretendiente supone la simultaneidad de coexistencias irreductibles.

La genealogía de la moral nietzschiana revela una dialéctica acreedor-deudor en la historia de Occidente, para la cual, la burocratización estatal y sus registros escritos permiten las listas de morosos que han de pagar con sufrimiento y dolor el mero precio de la existencia bajo una dominación codificada. Para Deleuze el Estado se desvela como un mal estructural: «Es posible que, espiritual o temporal, tiránico o democrático, capitalista o socialista, no haya habido nunca más que un solo Estado" ${ }^{51}$. El Estado se nos muestra como la optimización hipócrita, mal estructural que ha existido siempre, contra el que se enfrenta el intelectual en cuanto desmitificador. El trabajo de Deleuze en este campo, como el de Foucault y tantos otros, no es el de intelectual orgánico, modelador de la voluntad política de los demás a los patrones dominantes, sino el de la reproblematización de lo establecido, función social del intelectual en cuanto ciudadano, con el fin de participar en la formación de la voluntad política de los ciudadanos.

La escritura estatal Occidental es descubierta por el ciudadano crítico como papel mojado. La abstracción filosófica, lejos de promover la razón social con la Declaración de los Derechos Humanos, acabó generando una razón instrumental; un mecanismo en el que la ley equivale al Nihilismo: «es propio de la ley significar sin designar nada. La ley no designa nada ni a nadie (la concepción democrática de la ley hará de ello un criterio) » ${ }^{52}$. La ley vacía de la social-

Antigüedad griega, he llegado a tener experiencias tan intempestivas en tanto que soy hijo de la época actual. Este punto tengo, por lo menos, derecho a concedérmelo por mi profesión de filólogo clásico: pues no sé que sentido podría tener la filología clásica en nuestra época, si no es el de obrar de una manera intempestiva -es decir, contraria al tiempo y, por esto mismo, sobre el tiempo y en favor, asl lo espero, de un tiempo futuro".

49 LS, Apéndice I.1, pág. 266: «Es propio de la Filosofía no ser moderna a cualquier precio..., sino desprender de la modernidad algo que Nietzsche designaba como lo intempestivo, que pertenece a la modernidad, pero que también ha de ser puesto contra ella».

so LS, apéndice I.1, pág.263.

51 Gilles Deleuze / Felix GuATtar El Antiedipo. Capitalismo y esquizofrenia. Ed. SeixBarral. Barcelona 1972, pág. 199. (Trad.Francisco Monge).

52 Ibid. op.cit.pág. 220. 
democracia contemporánea es el nihilismo reactivo, frente al que se yergue el nihilismo afirmativo, el aprovechamiento del vacío legal, dentro de la legalidad, que surge cuando se adopta, por ejemplo, la desobediencia civil; el aprovechamiento de los principios, incumplidos con tanta obstinación como proclamados, por ejemplo, cuando se desenmascara la censura de los supuestos defensores de la libertad de expresión. Denuncia de la hipocresía y aprovechamiento de los vacíos siempre existentes.

¿Qué haremos en nuestra madura modernidad una vez desmitificada la Razón?. ¿Abandonaremos la filosofía y la escritura?. ¿Nos arrojaremos en los brazos del Mito?. ¿En las manos de los magos y de los profetas, de la no menos ambigua oralidad arcaica?. ¿O estará próximo el momento de aplicarle la sospecha a la hermenéutica de la sospecha, desmitificándola a su vez, y volver a la razón, esta vez, lejos de la hipocresía; para reescribir sin espejismos la República platónica?. Creemos que el pensamiento de Deleuze admite, finalmente, ambas posturas encontradas, si bien nosotros, claramente, suscribimos la segunda. La continuación de una razón que se sabe finita y que al hacerse adulta y crítica abandonando la minoría de edad, abandona junto a ella los mitos y las hipocresías, es la tarea a realizar para el siglo XXI. Después de la destrucción de ídolos del nihilismo afirmativo y la erradicación de la reactividad, hay que volver a construir. 